\section{Air quality assessment in Southeast Brazil during COVID-19 pandemic and lockdown: report of increased air pollution}

\author{
Avaliação da qualidade do ar no Sudeste do \\ Brasil durante a pandemia da COVID-19 e \\ do confinamento: relato de aumento da \\ poluição atmosférica
}

Evaluación de la calidad del aire en el sudeste de Brasil durante la pandemia de COVID-19y confinamiento: informe de una mayor contaminación del aire
Bruno Kabke Bainy ${ }^{1}$

Ilma Aparecida Paschoal 2

Ana Maria Heuminski de Avila 1

Henrique Oliveira dos Santos 3

doi: 10.1590/0102-311X00242320

\begin{abstract}
On March 24, 2020, a partial lockdown was decreed in the state of São Paulo, Brazil, as a measure to hinder the spread of COVID-19, which consisted in prohibiting crowding and advising people to stay home, except for urgent or extremely necessary matters. Based on studies performed in other countries, this study aims to assess the impacts of the lockdown on the air quality of five cities in the state of São Paulo. Our study was conducted by using particulate matter and nitrogen dioxide as air quality indicators, and by correlating the contaminants concentrations with weather data. The results showed an increase in these contaminants in all cities within the first weeks after the lockdown compared with the weeks before the decree and with the same period in previous years. This result is inconsistent with the literature. Therefore, a secondary goal was set to investigate the possible cause (or causes) of such deterioration in air quality, which led to the increased number of wildfires. The anomalous dry weather favored the burning of vegetation in agricultural rural areas and in small, vegetated areas near the municipalities, and limited pollution scavenging by rainfall, both of which contributed to higher pollution concentration. We hypothesize the possible effects of worse air quality on the aggravation of COVID-19, but further research is necessary to obtain a complete assessment.
\end{abstract}

Air Pollution; Particulate Matter; Nitrogen Dioxide; COVID-19; Wildfires

\author{
Correspondence \\ B. K. Bainy \\ Centro de Pesquisas Meteorológicas e Climáticas Aplicadas à \\ Agricultura, Universidade Estadual de Campinas. \\ Av. Dr. André Tosello 209, Campinas, SP 13083-970, Brasil. \\ bkbainy@cpa.unicamp.br \\ 1 Centro de Pesquisas Meteorológicas e Climáticas Aplicadas à \\ Agricultura, Universidade Estadual de Campinas, Campinas, \\ Brasil. \\ 2 Faculdade de Ciências Médicas, Universidade Estadual de \\ Campinas, Campinas, Brasil. \\ 3 Faculdade de Engenharia Mecânica, Universidade Estadual de \\ Campinas, Campinas, Brasil.
}




\section{Introduction}

Coronaviruses are pathogens that affect animals and humans causing digestive and respiratory diseases. In 2002 and 2003, after outbreaks of a severe acute respiratory syndrome in Guangdong, China, the causative agent was found to be a coronavirus that received then the denomination of SARS-CoV 1,2,3. The origin of the infection was thought to be the civets that were sold in a livestock market. One decade later, another outbreak of severe acute respiratory syndrome, this time in Middle East, was attributed to a novel coronavirus that was named MERS-CoV 4. The coronavirus responsible for this current pandemic was designated as SARS-CoV-2 - due to its resemblance to SARS-CoV -, and the disease was named COVID-19 5,6.

Several countries and regions around the world have adopted the social distancing policy as an extreme measure to limit the spread of COVID-19 and to flatten the curve of confirmed cases of the disease. This policy often implies measures that range from a small degree of reduction in social interaction to complete lockdown, and its consequences are felt in many ways: economy, sociology, epidemiology, psychology, and others. One of the aspects that have been studied globally is the behavior of air quality during the social distancing period.

Studies have been carried out worldwide, at regional and national levels, with most results, if not all, indicate to decreased air pollution levels as a response to lockdown. In Barcelona, Spain, black carbon $(\mathrm{BC})$ and nitrogen dioxide $\left(\mathrm{NO}_{2}\right)$ levels dropped significantly, followed by a smaller decrease in fine particulate matter (aerodynamic diameter smaller than $10 \mu \mathrm{m}$ - PM10), attributed mainly to the social restrictions and smaller traffic 7 . In India, a similar study considering six pollutants measured in 22 cities across the country over the first month of the lockdown, and compared with the same period of previous years, showed significant reduction in most pollutants: fine and ultra-fine particulate matter (PM10 and PM2.5, respectively), carbon monoxide (CO) and $\mathrm{NO}_{2}{ }^{8}$. The same study also assessed the effectiveness of meteorological features on pollution dispersion, concluding that, even though weather may interfere with air pollution, air quality improved in India during the lockdown due to the imposed restrictions on human interaction and activities. In Italy, research was conducted in the metropolitan area of Milan to assess air pollution levels under the partial and subsequent total lockdown that was imposed by the government. The control period prior to the lockdowns was selected based on meteorological homogeneity in relation to the lockdowns. The research found that most pollutants significantly decreased, especially those related to vehicular traffic, which led to the conclusion that this drop was mostly caused by the lockdowns ${ }^{9}$. In Brazil, a similar study was carried out focusing on the São Paulo Metropolitan Area, in the state of São Paulo. Seven pollutants were analyzed with data from four air quality stations during four weeks before and after partial lockdown, and the data were compared with the means for the preceding five years. All pollutants had drastic reductions, except for ozone $\left(\mathrm{O}_{3}\right.$, whose concentration increased during lockdown) 10 .

This study aims to assess any impacts the lockdown may have had on the air quality in five cities in the state of São Paulo, and to discuss the possible outcomes of such impacts on COVID-19 cases in these locations.

\section{Data and methodology}

São Paulo is the most populous and richest Brazilian state, with Gross Domestic Product (GDP) that represents $31.93 \%$ of the country's GDP, according to the Brazilian Institute of Geography and Statistics (IBGE; https://www.ibge.gov.br/explica/pib.php, accessed on 27/Jul/2020) and the State Data Analysis System Foundation (SEADE; https://www.seade.gov.br/produtos/pib-anual/, accessed on 27/Jul/2020). Geographically, it is crossed by the Tropic of Capricorn and is located within the latitudes of $19^{\circ}$ and $26^{\circ} \mathrm{S}$ and the longitudes of $53^{\circ}$ and $44^{\circ} \mathrm{W}$ (Figure 1 ).

The Campinas Metropolitan Area is composed of 20 municipalities, including Americana and Paulínia, occupying an area of $3,792 \mathrm{~km}^{2}$, with a population of approximately $2,976,400$ people (Campinas Metropolitan Agency - AGEMCAMP. http://www.agemcamp.sp.gov.br/produtos/perfilrnc/view/grafico.php, accessed on 17/Jul/2020). It is surrounded by several important highways and hosts a diversified industrial complex, which includes Petrobras' largest oil refinery, processing 


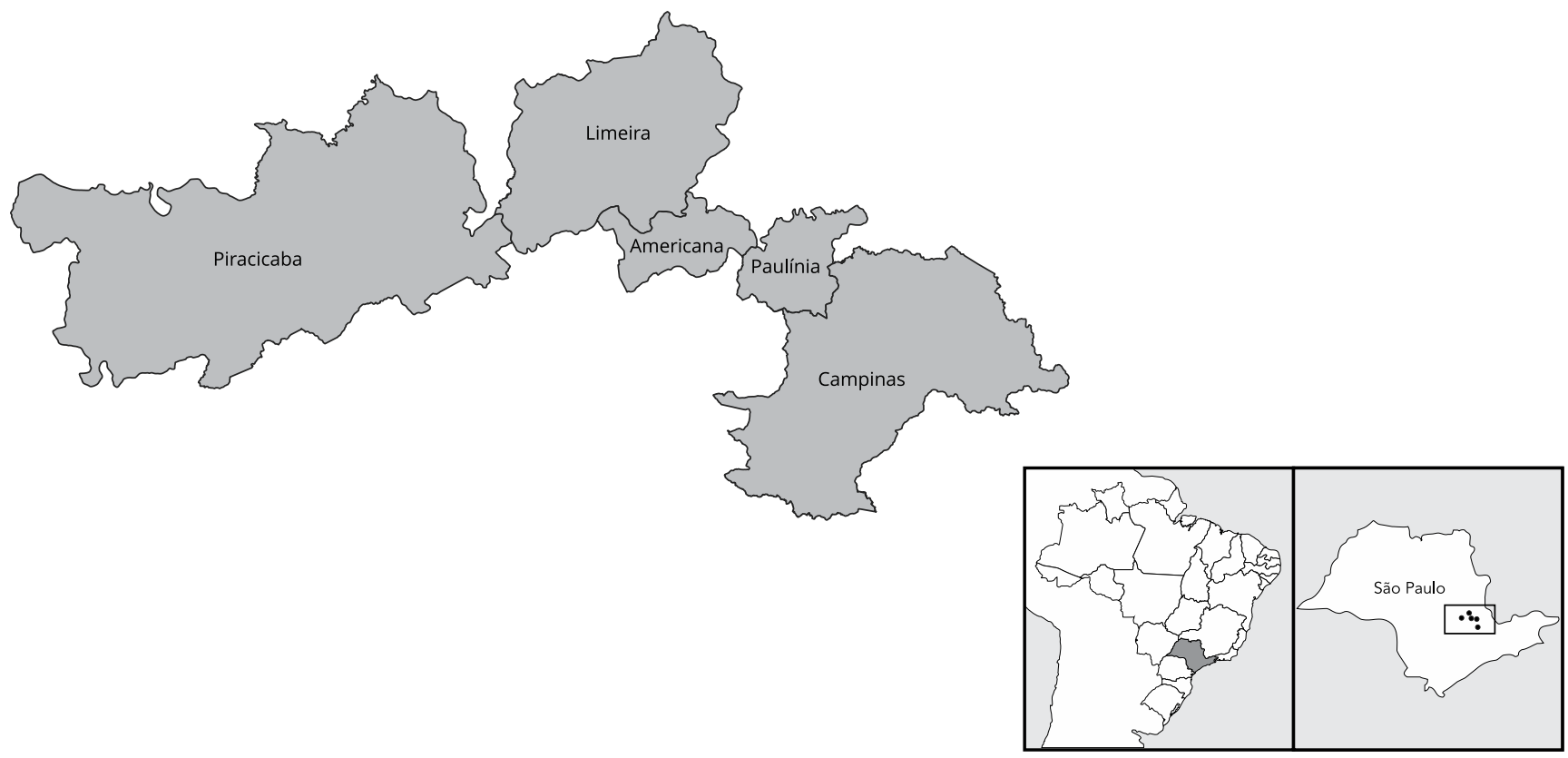

approximately 434,000 oil barrels per day (Petrobras. https://petrobras.com.br/pt/nossas-ativida des/principais-operacoes/refinarias/refinaria-de-paulinia-replan.htm, accessed on 17/Jul/2020). In 2018, the Campinas Metropolitan Area vehicular fleet was composed of 2,274,791 vehicles, out of which $94.68 \%$ corresponded to light vehicles (cars, motorbikes, small trucks, and microbuses), $4.74 \%$ were large trucks, and 0.55\% were buses (AGEMCAMP. http://www.agemcamp.sp.gov.br/, accessed on 17/Jul/2020). Limeira and Piracicaba are neighboring cities outside the Campinas Metropolitan Area. Their estimated populations as of 2019 are approximately 306,000 and 404,000 inhabitants, and their vehicle fleets are composed of 216,775 (93.7\%) and 306,582 (93.13\%) vehicles (light vehicle percentage), respectively (IBGE. https://cidades.ibge.gov.br/, accessed on 17/Jul/2020). Regarding agriculture, the main cultures are pasture (for cattle), sugar cane, fruits (citrus, grapes, figs), and vegetables 11,12. Figure 1 shows the locations of the analyzed municipalities.

The State of São Paulo officially established the social distancing policy on March 24, 2020, and the government has been assessing mobile phone data daily in order to estimate the efficacy of the policy using a social distancing index (SDI), which is expressed in percentage and has been estimated for every city within the state since March 5 (https://www.saopaulo.sp.gov.br/coronavirus/isolamen to/, accessed on 06/May/2020).

Daily means for particulate matter with diameter smaller than 10 micrometer (PM10) and 2.5 micrometer (PM2.5), and the maximum hourly mean per day of $\mathrm{NO}_{2}$ were the air quality data obtained from the São Paulo State Environmental Agency (CETESB. https://qualar.cetesb.sp.gov. $\mathrm{br} /$ qualar/home.do, accessed on 05/May/2020) - used as traces of air pollution in Americana, Campinas, Limeira, Paulínia, and Piracicaba from February 1 to May 5, 2020. These data were used to compare the concentration time series before and after social distancing started. Furthermore, PM10 data for Campinas, for the same period of the year over the years of 2015-2019, were used as proxy for air quality and were compared with 2020 . This approach enabled assessing intra- and inter-annual variability. 
Since atmospheric conditions may help or hinder air pollution dispersion, weather data were also collected and used to qualitatively evaluate the influence of atmospheric patterns on the dispersion. We used daily rainfall data (0-24h local time) collected at a weather station located at the University of Campinas (Campus Campinas), while data for the other cities were obtained from the São Paulo State's Agrometeorological and Hydrological Webpage (http://ciiagro.org.br/, accessed on 06/May/2020).

Daily mean wind speed and direction were also collected by the air quality stations. Synoptic charts were used to visualize the large-scale weather features that affected the area - especially high- and low-pressure systems and cold fronts - during some selected episodes of relative higher and lower pollution concentrations that occurred within the studied period in 2020. Finally, it was necessary to include fire spots data from February 1 to May 5, due to reports of a significant increase in wildfires in the region in 2020. These data are satellite-derived by Brazil's National Institute for Space Research (INPE), and generally they can detect fire fronts with dimensions of 30x1m. The data, further details, and their assumptions and limitations are available at the INPE's Satellite Division webpage (http://queimadas.dgi.inpe.br/queimadas/portal, accessed on 10/May/2020).

\section{Results}

On average, the social distancing index from March 24 to May 5 was 52.4\%, with maximum of $63 \%$ and lowest of $45 \%$. Before social distancing was recommended and decreed, the index ranged from 27 to $30 \%$.

Figure 2 shows the daily-averaged PM10 and PM2.5, daily maximum of $1 \mathrm{~h}-$ average $\mathrm{NO}_{2}$ concentrations, the daily accumulated rainfall, and the daily averaged wind speed from February 1 to May 5. Visually, it is noticeable that the concentrations follow approximately the same patterns in all the displayed cities, and that there is a consistent and sharp increase in concentrations for all pollutants from mid-April. While February had plenty of rain (considering both the number of days with precipitation and the respective totals), March had fewer rainy days and the volumes were typically smaller, and April had no record of precipitation, except for one day in Americana. The graph shows that rainfall is followed by a decrease in contaminant concentrations. Wind speed also seems to be a modulator of pollution concentrations, with higher speeds leading to lower concentrations. Note that lower wind speeds occurred from April on, even though there were some windier days on occasions. To assess any inter-annual variability, Figure 3 shows a comparison of PM10 concentrations, used as a proxy for air quality, from February 1 to May 5 from 2015 to 2020. PM10 concentrations in 2020 were very similar to the three years prior (with slightly higher values), even under partial lockdown, but still lower than those of 2015 and 2016.

Statistically, wind correlates with particulate matter ranging from -0.41 to -0.49 , with the highest negative correlations occurring between wind speed and PM10, and precipitation correlates with particulate matter ranging from -0.16 to -0.36 , which shows the expected influence of atmospheric conditions on air pollution dispersion that may be more or less intense depending on the interaction between the scales of meteorological phenomena. Synoptic analyses of some selected cases of relatively high and low concentrations indicate that the larger scale meteorological conditions that favored lower PM concentrations were associated with the passage of cold fronts and the approach of the anticyclone that follows, or of the South Atlantic Convergence Zone (due to stronger wind speeds and rainfall that usually follow these patterns). The relatively higher concentrations occurred with no defined synoptic system, usually with the South Atlantic Subtropical High to the Southeast, further into the ocean, and an equivalent barotropic atmosphere over the state of São Paulo.

Table 1 shows the statistics for the pollutants and for each of the cities in which their concentrations are measured. In all cases, the concentrations were higher after the social distancing policy was established than before. The satellite-derived product that identifies fire spots, operated by the INPE, indicated a significant increase in fire spots in 2020, compared to previous years, especially in April. Table 2 shows the satellite-derived counts of fire spots for the cities included in this study and for the selected time frame for the past years. Those figures are an estimate, since there are some limitations in the methodology; however, they provide a general sense on how these cities are affected by fires, 


\section{Figure 2}

Daily averaged PM10 and PM2.5 concentrations, maximum 1-hour average concentration of $\mathrm{NO}_{2}$, average wind speed, and accumulated rainfall.

2a) PM10
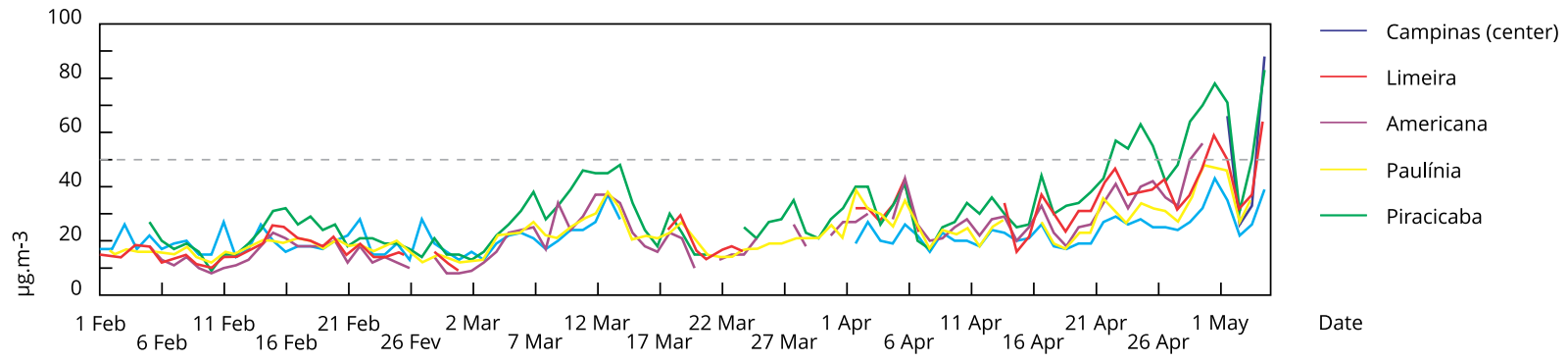

2b) PM2.5
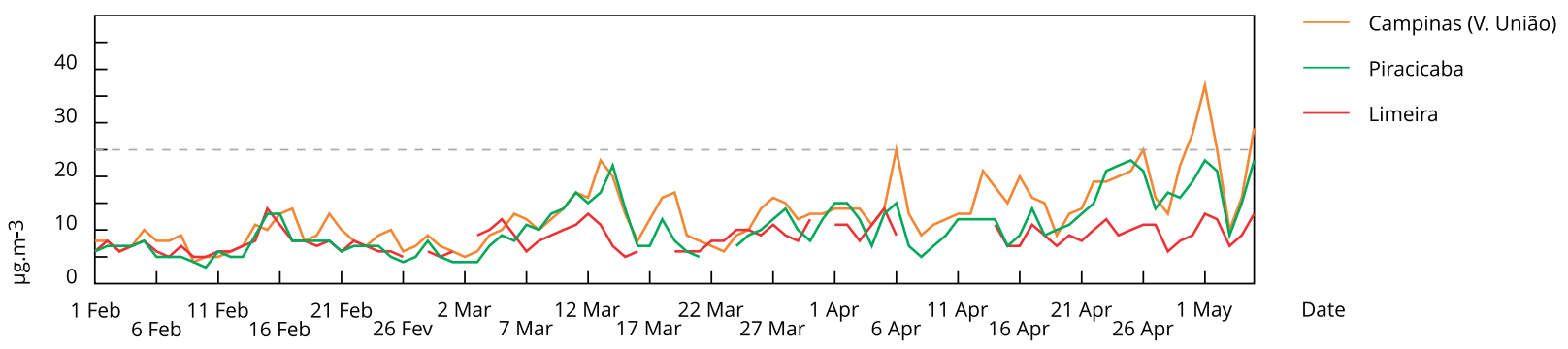

2c) $\mathrm{NO}_{2}$
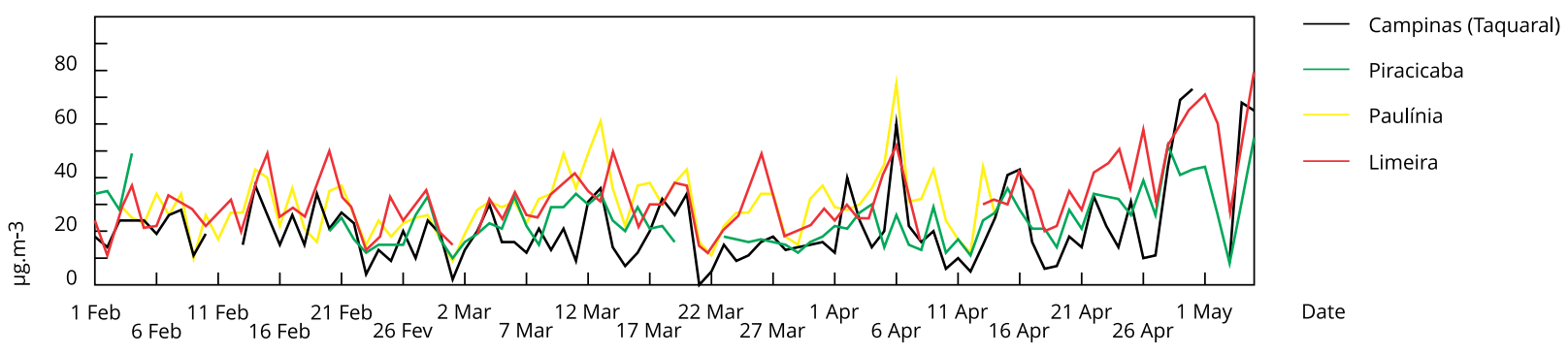

(continues) 
Figure 2 (continued)

2d) Wind speed

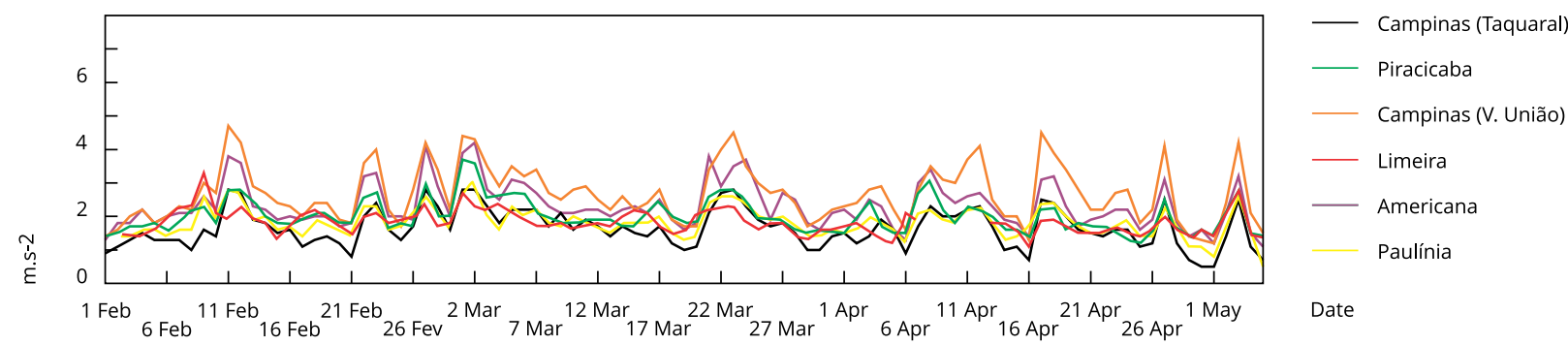

2e) Rainfall

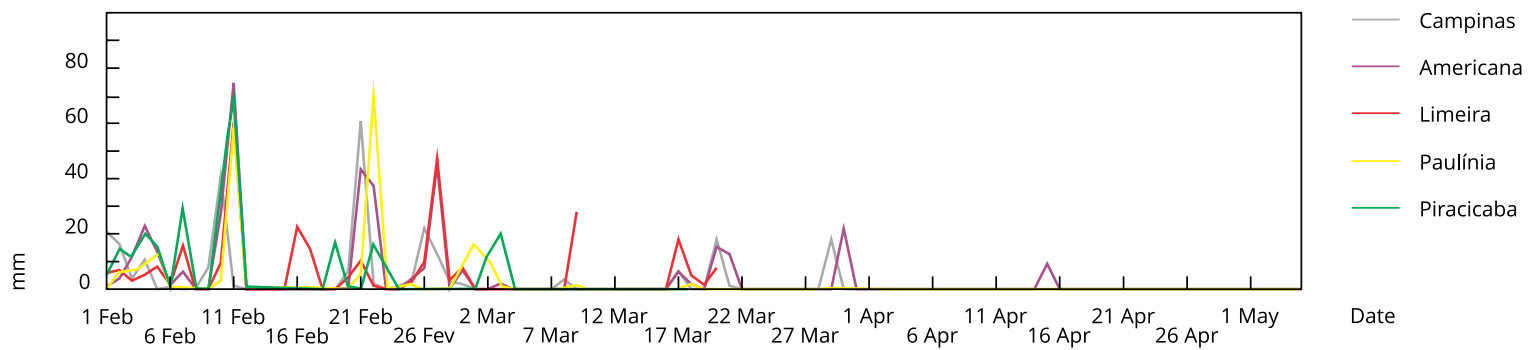

Note: horizontal dashed white lines on $2 \mathrm{a}$ and $2 \mathrm{~b}$ represent World Health Organization guidelines 16.

Figure 3

Boxplots for PM10 concentrations measured at downtown Campinas, São Paulo State, Brazil, 2015-2020.

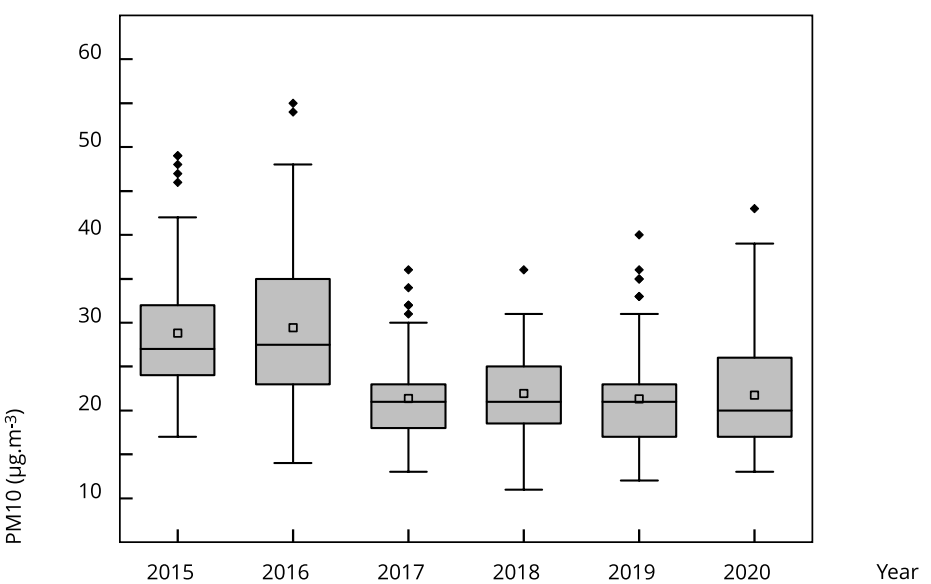


Table 1

Statistical description of the PM10, PM2.5, and $\mathrm{NO}_{2}\left(\mu \mathrm{g} \cdot \mathrm{m}-{ }^{3}\right)$ according to data availability, for the whole period, and for before and after the social distancing policy.

\begin{tabular}{|c|c|c|c|c|c|c|c|c|c|}
\hline \multirow[t]{2}{*}{ Municipality } & \multirow[t]{2}{*}{ Overall mean } & \multicolumn{4}{|c|}{ Before social distancing } & \multicolumn{4}{|c|}{ After social distancing } \\
\hline & & Mean & SD & Maximum & Median & Mean & SD & Maximum & Median \\
\hline \multicolumn{10}{|l|}{ PM10 } \\
\hline Campinas (center) & 21.76 & 19.93 & 5.08 & 37.00 & 19.00 & 24.06 & 6.12 & 43.00 & 23.00 \\
\hline Americana & 23.99 & 17.65 & 7.62 & 37.00 & 16.50 & 31.66 & 14.21 & 88.00 & 27.50 \\
\hline Piracicaba & 31.42 & 24.30 & 9.64 & 48.00 & 21.50 & 39.02 & 16.49 & 83.00 & 34.00 \\
\hline Limeira & 25.90 & 20.02 & 7.96 & 47.00 & 18.00 & 35.83 & 11.65 & 69.00 & 34.00 \\
\hline Paulínia & 22.72 & 19.25 & 5.32 & 38.00 & 18.50 & 27.23 & 8.26 & 48.00 & 25.50 \\
\hline \multicolumn{10}{|l|}{ PM2.5 } \\
\hline Campinas (V. União) & 12.81 & 9.83 & 5.98 & 23.00 & 9.00 & 16.42 & 6.02 & 37.00 & 14.00 \\
\hline Piracicaba & 10.48 & 8.16 & 5.13 & 22.00 & 7.00 & 13.19 & 4.98 & 23.00 & 12.00 \\
\hline Limeira & 8.47 & 7.52 & 2.35 & 14.00 & 7.00 & 9.77 & 1.94 & 14.00 & 10.00 \\
\hline \multicolumn{10}{|l|}{$\mathrm{NO}_{2}$} \\
\hline Campinas (Taquaral) & 21.37 & 19.00 & 8.88 & 37.00 & 19.00 & 24.27 & 19.00 & 73.00 & 16.00 \\
\hline Piracicaba & 24.43 & 23.71 & 8.43 & 49.00 & 22.00 & 25.00 & 11.08 & 55.00 & 24.00 \\
\hline Paulínia & 29.49 & 28.54 & 10.54 & 61.00 & 27.00 & 31.64 & 13.13 & 75.00 & 30.50 \\
\hline Limeira & 32.68 & 28.76 & 9.45 & 50.00 & 29.00 & 37.79 & 16.00 & 80.00 & 32.00 \\
\hline
\end{tabular}

SD: standard deviation.

Table 2

Number of fire spots detected by satellite from February 1st to May 5th, 2015-2020.

\begin{tabular}{|c|c|c|c|c|c|c|}
\hline Municipality & 2015 & 2016 & 2017 & 2018 & 2019 & 2020 \\
\hline Americana & 4 & 13 & 4 & 6 & 7 & 10 \\
\hline Campinas & 9 & 53 & 31 & 22 & 12 & 84 \\
\hline Limeira & 10 & 32 & 9 & 12 & 9 & 50 \\
\hline Paulínia & 4 & 12 & 6 & 9 & 27 & 10 \\
\hline Piracicaba & 7 & 42 & 1 & 20 & 25 & 67 \\
\hline Total & 34 & 152 & 51 & 69 & 80 & 221 \\
\hline
\end{tabular}

and they are based on a consistent methodology. In addition to the information in Table 2, the local Civil Defense in Campinas informed the authors of 18 other spots not detected by satellite in April and 19 in May (up to the 20th of the month).

\section{Discussion}

The data presented here is inconsistent with the findings of all the other studies referred to in this paper, which show a decrease in concentrations of particulate matter and nitrogen dioxide (among other pollutants) in response to the social distancing measures. This fact raises the questions: What is causing increased concentrations of these contaminants? And what are the possible effects of the higher concentrations on the severity of COVID-19 cases, especially for the risk groups? 
Since human activities were reduced or completely suspended in several sectors, and since the social distancing policy was somewhat effective in keeping people home, at least some reduction in the emission of atmospheric pollution would be expected, mainly due to a drastic reduction in vehicular traffic. Such was the conclusion of the aforementioned studies 7,8,9,10. Considering the impact of COVID-19 on the local industrial production in the early months of 2020, almost every sector experienced a reduction (compared to 2019), ranging from 1.3\% in pharmaceutical and pharmochemical production to $33.94 \%$ in production of transportation equipment other than automotive vehicles 13 . According to the same technical note 13, there were few exceptions: the industrial sectors of hygiene products (soaps, detergents, cleaning products, cosmetics, and others; 14.69\%), the production of machines and equipment (9.22\%), the production of other chemicals (5.02\%), and the cellulose and paper industry (3.92\%), which grew in response to higher demands due to emerging needs stemming from the pandemic, to the non-stopping agricultural production and to the shortage of some items in the global market. Oil production data 14 for the Paulínia Refinery (REPLAN) showed that the total oil production from February to June was the lowest since 2015, undergoing a recovery after that. Regarding the impact of the pandemic on agriculture, the authors found no publication reporting direct impact from COVID-19 and its implications, nor from the drought on the production and production capability within the geographical area of the study. The trade of fresh fruits and vegetables, however, was highly affected by the restrictions imposed by social distancing, which drastically reduced the purchases by restaurants and final consumers.

Another possible pollution source needs to be explored to explain the worsening of air quality in these locations within a few weeks of partial lockdown. We evaluated the satellite-derived information about wildfire spots, which led to the conclusion that the higher air pollution concentrations may be attributed to the increased number of wildfires. The weather conditions (drought) that favored the start and spread of the fires also contributed to a smaller dispersion/deposition of pollutants, especially by scavenging due to the dragging of pollution by rain drops. As a matter of fact, April of 2020 was the driest April in Campinas and in its area since weather observations started. The provisional climatological mean for precipitation in the region is around $65 \mathrm{~mm}$ in April, whereas in 2020 Campinas had no record of rainfall during April and early May, and Americana had extraordinarily little rain $(9.14 \mathrm{~mm})$.

PM is a widely studied atmospheric pollutant, being commonly used as a proxy for indicating air quality level 15 . The classification into coarse and fine particulate matter is based on the aerodynamical diameter, which is, respectively, smaller than $10 \mu \mathrm{m}$ (PM10) and smaller than $2.5 \mu \mathrm{m}$ (PM2.5). The PM10 can penetrate the proximal airways, whereas PM2.5 can go further into the alveolus and the bloodstream 15 . In both cases, PM is evidenced to cause adverse health effects in long- and short-term exposures, leading to premature death and aggravating respiratory and cardiovascular issues 16 . A comprehensive review of PM and its effects on human health was published by Kim et al. ${ }^{17}$. The

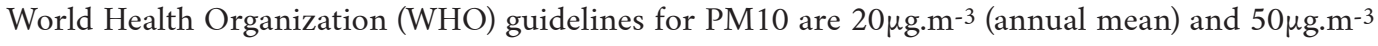
(24-hour mean), and for PM2.5 the thresholds are $10 \mu \mathrm{g} \cdot \mathrm{m}^{-3}$ and $25 \mu \mathrm{g} \cdot \mathrm{m}^{-3}$ for annual and 24-hour means, respectively 16 . Therefore, there were critical air quality episodes for both PM10 (Americana, Limeira, and Piracicaba) and PM2.5 (Campinas - V. União), nearly all of them within the last few days covered by this study. Furthermore, even though the time frame of the study is smaller than a year, most of the concentration means computed from March 24 to May 5 exceed the long-term values recommended by the WHO. $\mathrm{NO}_{2}$, which also compounds an important fraction of PM2.5, is associated with the worsening of bronchitis in asthmatic children and with reduced lung function 16 . The WHO guidelines for $\mathrm{NO}_{2}$ are $40 \mu \mathrm{g} \cdot \mathrm{m}^{-3}$ (annual mean) and $200 \mu \mathrm{g} \cdot \mathrm{m}^{-3}$ (1-hour mean). In this case, none of the thresholds were exceeded although $\mathrm{NO}_{2}$ concentrations increased on the last days of the assessed period. Ogen 18 assessed the impacts of $\mathrm{NO}_{2}$ on the mortality rates due to COVID-19 in areas of Italy, Spain, France and Germany, showing that most deaths occurred in northern Italy and central Spain, where the $\mathrm{NO}_{2}$ concentrations were the highest, which led to the conclusion that long-term exposure to this air contaminant may be important to explain the mortality trends in those areas.

The transmission of SARS-CoV-2 among humans is thought to occur primarily through inhalation of respiratory generated droplets and direct contact with respiratory secretions eliminated through the mouth and nose of an infected subject 1. Epidemiological models based solely on respiratory droplets and close contact have been considered insufficient to explain the regional differences in the spread pattern of COVID-19 5,6. 
Airborne transmission has been discussed as a possibility for virus dissemination, since it is well known that viral diseases spread very easily and rapidly; host factors that impart susceptibility are part of the reason for this viral success, but environmental phenomena may contribute to the global spread of many viruses. Viruses (and bacteria) are usually not air-dispersed as free particles, but are attached to soil dust and marine organic aggregates 19,20. Particulate matter concentration in the air deserves attention, since it may represent another means for virus dispersion.

SARS-CoV-2 is highly transmissible, and this characteristic is related to the high affinity of the spike protein of the virus capsid to a protein that integrates the cell membrane of many cells in different human organs, which is present in high density in the cell membranes of epithelial alveolar cells in the lungs 21,22 .

However, to reach the alveolar cells the virus must cross the layer of lung surfactant, a substance that results of the admixture of phospholipids, proteins and cholesterol. The main function of the surfactant is to reduce the surface tension inside the alveoli and thus to keep them open. It also has other functions, such as contributing to lung defense, through many different mechanisms. The various nitrogen oxides $\left(\mathrm{NO}_{\mathrm{X}}\right)$ present in the air of polluted areas may compromise cell membranes and the surfactant layer and facilitate the access of the virus to alveolar epithelial cells 23,24.

Although, at this time, we cannot provide an in-depth answer to the question of how increased air pollution may have favored or aggravated COVID-19 cases in the cities evaluated in this study which would require collecting more information (specially medical data) and further analysis -, we can reasonably assume that these higher concentrations might have, at least, facilitated the transmission of and the infection by the virus, as well as endangered people's health by making them more susceptible to severe cases of COVID-19.

\section{Conclusion}

Considering the severe adverse effects these pollutants cause in human health, mainly on lung function and respiratory diseases, the decrease in their concentrations is beneficial, considering the population as a whole and particularly those at risk for severe COVID-19, a group whose characteristics partly overlap with the people most sensitive to air pollution. The evidence presented here strongly suggests that, despite the expected drop in the concentrations of air pollutants, mostly due to decreased traffic in response to the lockdown, air quality has deteriorated because of a combination of unfavorable meteorological conditions for dispersion of air pollution and mainly of the occurrence of wildfires as pollution source. Further research efforts may be necessary to determine whether and to what extent the increased air pollution affected the population regarding respiratory diseases, with focus on severe cases of COVID-19. 


\section{Contributors}

B. K. Bainy contributed to the conceptualization, investigation, and writing of the original draft. I. A. Paschoal contributed to the writing, medical Input, review, and editing. A. M. H. Avila contributed to the writing, review, and editing. H. O. Santos contributed to the formal analysis. All authors approved the final version.

\section{Additional informations}

ORCID: Bruno Kabke Bainy (0000-0002-99008891); Ilma Aparecida Paschoal (0000-0002-05394243); Ana Maria Heuminski de Avila (0000-00026801-8528); Henrique Oliveira dos Santos (00000003-4145-7296).

\section{Acknowledgments}

We are very thankful to Sueli A. Castiglieri, from Campinas Civil Defense, for preparing and sending us the official counts and reports of wildfires, to Priscila Emerich Souza for preparing the figures, and to Silvia Oliveira for plotting the maps. The authors thank Espaço da Escrita, University of Campinas for the language services provided.

\section{References}

1. Khan S, Siddique R, Shereen MA, Ali A, Liu J, Bai Q, et al. Emergence of a novel coronavirus, severe acute respiratory syndrome coronavirus 2: biology and therapeutic options. J Clin Microbiol 2020; 58:e00187-20.

2. Cui J, Li F, Shi Z-L. Origin and evolution of pathogenic coronaviruses. Nat Rev Microbiol 2019; 17:181-92.

3. Zhong NS, Zheng BJ, Li YM, Poon LLM, Xie $\mathrm{ZH}$, Chan $\mathrm{KH}$, et al. Epidemiology and cause of severe acute respiratory syndrome (SARS) in Guangdong, People's Republic of China, in February, 2003. Lancet 2003; 362:1353-8.

4. Zaki AM, van Boheemen S, Bestebroer TM, Osterhaus ADME, Fouchier RAM. Isolation of a novel voronavirus from a man with pneumonia in Saudi Arabia. N Engl J Med 2012; 367:1814-20.

5. Cai J, Sun W, Huang J, Gamber M, Wu J, He G. Indirect virus transmission in cluster of COVID-19 cases, Wenzhou, China, 2020. Emerg Infect Dis 2020; 6:1343-5.

6. Setti L, Passarini F, De Gennaro G, Barbieri P, Pallavicini A, Ruscio M, et al. Searching for SARS-CoV-2 on particulate matter: a possible early indicator of COVID-19 epidemic recurrence. Int J Environ Res Public Health 2020; 17:2986.

7. Tobías A, Carnerero C, Reche C, Massagué J, Via M, Cruz Minguillón M, et al. Changes in air quality during the lockdown in Barcelona (Spain) one month into the SARS-CoV-2 epidemic. Sci Total Environ 2020; 726:138540.

8. Sharma S, Zhang M, Anshika, Gao J, Zhang H, Kota SH. Effect of restricted emissions during COVID-19 on air quality in India. Sci Total Environ 2020; 728:138878.

9. Collivignarelli MC, Abbà A, Bertanza G, Pedrazzani R, Ricciardi P, Miino MC. Lockdown for CoViD-2019 in Milan: what are the effects on air quality? Sci Total Environ 2020; 732:139280.

10. Nakada LYK, Urban RC. COVID-19 pandemic: impacts on the air quality during the partial lockdown in São Paulo state, Brazil. Sci Total Environ 2020; 730:139087.

11. Observatório Metropolitano. Região de Campinas: produção agropecuária. http://www. agemcamp.sp.gov.br/observatorio/index. php?option $=$ com_content $\&$ view $=$ article $\&$ id $=$ 756:regiao-de-campinas-producao-agrope cuaria- $\&$ catid $=2$ : noticias $\&$ Itemid $=8$ (accessed on 25/Jan/2021).

12. Figueira FA, Nicastro DL, Criscuolo C. Produção e organização de dados agrícolas da região metropolitana de Campinas para apoiar a elaboração de material didático pedagógico. In: Anais do 4o Congresso Interinstitucional de Iniciação Científica. https://www.ciic.cnptia. embrapa.br/arquivos/anais/anaisciic2010.rar. 
13. Oliveira PRS, Rosandiski EN. Nota técnica: impacto da Covid-19 na indústria de transformação 1T/2020. https://observatorio. puc-campinas.edu.br/nota-tecnica-impactoda-covid-19-na-industria-de-transformacao -1t-2020/ (accessed on 25/Jan/2021).

14. Agência Nacional do Petróleo, Gás Natural e Biocombustíveis. Processamento de petróleo e produção de derivados. https://www.gov.br/ anp/pt-br/centrais-de-conteudo/dados-aber tos/processamento-de-petroleo-e-producaode-derivados (accessed on 25/Jan/2021).

15. World Health Organization. Ambient (outdoor) air pollution. https://www.who.int/ news-room/fact-sheets/detail/ambient(outdoor)-air-quality-and-health (accessed on 08/Jun/2020).

16. World Health Organization. WHO air quality guidelines for particulate matter, ozone, nitrogen dioxide and sulfur dioxide. Geneva: World Health Organization; 2006.

17. Kim K-H, Kabir E, Kabir S. A review on the human health impact of airborne particulate matter. Environ Int 2015; 74:136-43.

18. Ogen $\mathrm{Y}$. Assessing nitrogen dioxide $\left(\mathrm{NO}_{2}\right)$ levels as a contributing factor to coronavirus (COVID-19) fatality. Sci Total Environ 2020; $726: 138605$
19. Aller JY, Kuznetsova MR, Jahns CJ, Kemp PF. The sea surface microlayer as a source of viral and bacterial enrichment in marine aerosols. J Aerosol Sci 2005; 36:801-12.

20. Yamaguchi N, Ichijo T, Sakotani A, Baba T, Nasu M. Global dispersion of bacterial cells on Asian dust. Sci Rep 2012; 2:525.

21. Gheblawi M, Wang K, Viveiros A, Nguyen Q, Zhong J-C, Turner AJ, et al. Angiotensinconverting enzyme 2: SARS-CoV-2 receptor and regulator of the renin-angiotensin system. Circ Res 2020; 126:1456-74.

22. Shyh G, Nawarskas JJ, Cheng-Lai A. ACE inhibitors and ARBs in patients with COVID-19: friend or foe? Cardiol Rev 2020; 28:213-6.

23. Kyono H, Kawai K. Morphometric study on age-dependent pulmonary lesions in rats exposed to nitrogen dioxide. Ind Health 1982; 20:73-99.

24. Hesterberg TW, Bunn WB, McClellan RO, Hamade AK, Long CM, Valberg PA. Critical review of the human data on short-term nitrogen dioxide $\left(\mathrm{NO}_{2}\right)$ exposures: evidence for $\mathrm{NO}_{2}$ no-effect levels. Crit Rev Toxicol 2009; 39:743-81. 


\section{Resumo}

Em 24 de março de 2020, foi decretado confinamento parcial no Estado de São Paulo, Brasil, como medida para desacelerar a disseminação da COVID-19. O decreto consistia na proibição de aglomerações e na recomendação para as pessoas permanecerem em casa, exceto em situações urgentes ou de extrema necessidade. Na esteira de estudos realizados em outros países, o artigo busca avaliar os impactos do confinamento na qualidade do ar em cinco cidades no Estado de São Paulo. Nosso estudo foi realizado com o material particulado e dióxido de nitrogênio enquanto indicadores da qualidade do ar e pela correlação das concentrações dos contaminantes com dados meteorológicos. Os resultados mostraram um aumento desses contaminantes em todas as cinco cidades dentro das primeiras semanas depois do confinamento, comparado às semanas que antecederam o decreto e com o mesmo período em anos anteriores. $O$ resultado é inconsistente com os achados usualmente relatados em outros estudos. Portanto, foi definido um objetivo secundário a fim de investigar a possível causa (ou causas) da piora na qualidade do ar, o que revelou um aumento no número de incêndios. O tempo anormalmente seco favoreceu a queima de vegetação nas áreas agrícolas rurais e em pequenas áreas de vegetação próximas às cidades, além do limitado escoamento da poluição pela chuva, o que contribuiu à maior concentração de poluentes. Os achados sugerem hipóteses sobre os possíveis efeitos dessa situação de pior qualidade do ar sobre o agravamento de casos de COVID-19, porém são necessários mais estudos para uma avaliação completa.

Poluição do Ar; Material Particulado; Dióxido de Nitrogênio; COVID-19; Incêndios Florestais

\section{Resumen}

El 24 de marzo de 2020 se decretó un confinamiento parcial en el estado de São Paulo, Brasil, como medida para evitar la propagación de la COVID-19, que consistió en prohibir aglomeraciones de personas y avisar a la gente que permaneciera en casa, salvo para asuntos urgentes o extremadamente necesarios. Siguiendo algunos estudios realizados en otros países, el objetivo de este trabajo es evaluar los impactos del confinamiento en la calidad del aire de ciudades en el estado de São Paulo. Nuestro estudio fue realizado usando material particulado y dióxido de nitrógeno, como indicadores de la calidad del aire, y mediante la correlación de las concentraciones de contaminantes con los datos meteorológicos. Los resultados mostraron un incremento en estos contaminantes en todas las ciudades dentro de las primeras semanas tras el confinamiento, comparando las semanas antes del decreto y dentro del mismo periodo en los años previos. Este resultado es inconsistente con aquellos que han sido informados en otros estudios. Por ello, un objetivo secundario fue investigar la posible causa (o causas) de tal deterioro en la calidad del aire, que conduce a un incremento en el número de incendios. La climatología seca anómala favoreció la quema de vegetación en las áreas rurales agrícolas, $y$ en áreas con poca vegetación cerca de las ciudades, y la eliminación limitada de la contaminación gracias a la lluvia, ambos contribuyeron a una mayor concentración de contaminación. Se especula que los posibles efectos de esta situación de una peor calidad del aire podrían afectar en el agravamiento de los casos de COVID-19, pero son quizás necesarias más investigaciones para conseguir una evaluación completa.

Contaminación del Aire; Material Particulado; Dióxido de Nitrógeno; COVID-19; Incendios Forestales
Submitted on $20 / \mathrm{Aug} / 2020$

Final version resubmitted on 06/Apr/2021 Approved on 26/Apr/2021 